\title{
Stable isotope food-web analysis and mercury biomagnification in polar bears (Ursus maritimus)
}

\author{
Travis W. Horton, ${ }^{1}$ Joel D. Blum, ${ }^{2}$ Zhouqing Xie ${ }^{2}$ Michael Hren ${ }^{3}$ \& C. Page Chamberlain ${ }^{4}$ \\ 1 Department of Geological Sciences, University of Canterbury, Private Bag 4800, Christchurch 8140, New Zealand \\ 2 Department of Geological Sciences, University of Michigan, Ann Arbor, MI 48109-1005, USA \\ 3 Geology and Geophysics Department, Yale University, P.O. Box 208109, New Haven, CT 06520-8109, USA \\ 4 Geological and Environmental Science Department, Stanford University, Stanford, CA 94305-2115, USA
}

\section{Keywords}

Arctic; food webs; pelagic; polar bears;

stable isotopes; sympagic.

\section{Correspondence}

Travis W. Horton, Department of Geological Sciences, University of Canterbury, Private Bag 4800, Christchurch 8140, New Zealand. E-mail: travis.horton@canterbury.ac.nz

doi:10.1111/j.1751-8369.2009.00114.x

\begin{abstract}
Mercury (Hg) biomagnification occurs in many ecosystems, resulting in a greater potential for toxicological effects in higher-level trophic feeders. However, Hg transport pathways through different food-web channels are not well known, particularly in high-latitude systems affected by the atmospheric $\mathrm{Hg}$ deposition associated with snow and ice. Here, we report on stable carbon and nitrogen isotope ratios, and Hg concentrations, determined for 26, late 19th and early 20th century, polar bear (Ursus maritimus) hair specimens, collected from catalogued museum collections. These data elucidate relationships between the high-latitude marine food-web structure and $\mathrm{Hg}$ concentrations in polar bears. The carbon isotope compositions of polar bear hairs suggest that polar bears derive nutrition from coupled food-web channels, based in pelagic and sympagic primary producers, whereas the nitrogen isotope compositions indicate that polar bears occupy $>$ fourth-level trophic positions. Our results show a positive correlation between polar bear hair $\mathrm{Hg}$ concentrations and $\delta^{15} \mathrm{~N}$. Interpretation of the stable isotope data in combination with $\mathrm{Hg}$ concentrations tentatively suggests that polar bears participating in predominantly pelagic food webs exhibit higher mercury concentrations than polar bears participating in predominantly sympagic food webs.
\end{abstract}

The warming of the Arctic is predicted to significantly reduce Arctic sea ice (Overpeck et al. 2005), to impact marine food webs and to potentially threaten extant polar bear (Ursus maritimus) populations, because of the loss of seal hunting habitat (Hassol 2004). The atmospheric deposition of high levels of mercury $(\mathrm{Hg})$ during the Arctic springtime (Ariya et al. 2004) may pose an additional threat to these top predators. Despite many valuable contributions to our understanding of trophic structure and $\mathrm{Hg}$ cycling in Arctic marine systems (Braune et al. 2005), the relationships between food-web structure and $\mathrm{Hg}$ transport pathways through Arctic food chains represent an understudied component of the highlatitude mercury cycle (Bradstreet \& Cross 1982; Atwell et al. 1998; Lu et al. 2001; Fitzgerald et al. 2005; Outridge, Hobson et al. 2005). For example, a correlation was demonstrated between trophic position (determined from changes in $\delta^{15} \mathrm{~N}$ values between predator and prey) and
$\mathrm{Hg}$ concentration in the muscle tissues of marine fauna collected between 1988 and 1990 in Canada's Lancaster Sound ecosystem (Atwell et al. 1998). However, this correlation excluded polar bears. A more recent study shows a similar correlation that includes polar bears (Dehn et al. 2006). However, this trend is equivocal, as it is based on $\delta^{15} \mathrm{~N}$ values determined on muscle tissue, and total $\mathrm{Hg}$ concentrations determined on liver tissue. Another study finds that mercury is biomagnified between polar bear and seal livers, but not between polar bear and seal muscle (Woshner et al. 2001). The lack of clear evidence for or against $\mathrm{Hg}$ biomagnification in polar bear tissues raises questions about the ecological, biological and physiological processes, conditions and behaviours that influence the fate and transport of $\mathrm{Hg}$ through highlatitude food webs.

Recent studies suggest that high-latitude ecosystems have a heightened potential for $\mathrm{Hg}$ toxicity as a result of 
the net deposition of ca. 300 tonnes of atmospheric $\mathrm{Hg}$ in the Arctic each year, primarily occuring during spring atmospheric Hg-depletion events (Ariya et al. 2004). Several investigations further indicate that the net deposition of $\mathrm{Hg}$ in high-latitude environments has increased during the last century. A study of $\mathrm{Hg}$ in Greenlandic polar bear hairs collected between 1892 and 2001 showed very little change in $\mathrm{Hg}$ concentration up to about 1950 , with a large increase in more recent times, presumably as a result of the increased anthropogenic inputs of $\mathrm{Hg}$ to the atmosphere (Dietz, Riget, Born et al. 2006). This is generally consistent with records of atmospheric $\mathrm{Hg}$ deposition in the Northern Hemisphere in glacial ice cores (Schuster et al. 2002) and lake sediments (Fitzgerald et al. 2005; Outridge, Stern et al. 2005), which exhibit large increases in $\mathrm{Hg}$ deposition between ca. 1950 and the present. Given these trends in $\mathrm{Hg}$ deposition, it is important to assess the ecological conditions of $\mathrm{Hg}$ transport through high-latitude food webs.

In this study, we determined the stable carbon and nitrogen isotopic compositions, and $\mathrm{Hg}$ concentrations, in 26 polar bear hair specimens collected from throughout the Arctic prior to 1950. Our primary goal was to investigate the influence of trophic position and food-web structure on $\mathrm{Hg}$ concentrations in polar bears from the time period prior to the most significant anthropogenic increases in atmospheric $\mathrm{Hg}$ deposition, and prior to the impact of modern climate change on sea-ice extent in the Arctic. This study provides a baseline from which current and future effects of $\mathrm{Hg}$ deposition and climate change on polar bear $\mathrm{Hg}$ exposure can be referenced.

\section{Materials and methods}

Hair samples from 26 polar bears were obtained from the National Museum of Natural History in Washington, D.C., the Harvard Museum of Comparative Zoology in Cambridge, MA, and the American Museum of Natural History in New York, for stable isotope ratio and Hg concentration analyses. Museum staff cut 50-100-mg guard hair specimens from the ventral section of the catalogued museum polar bear pelts. Specimen collection dates range from 1881 to 1946, and the collection locations span the Arctic Basin (Fig. 1; Table 1). Of the 26 samples collected, all 26 have specific collection dates, but only 14 have specific collection locations recorded in the various museum catalogues.

Stable isotope analyses were performed at the Department of Geological and Environmental Sciences, Stanford University. All samples were washed in a weak $(<0.01 \%)$ sodium hydroxide-based detergent, rinsed three times in deionized water and were then allowed to dry in air overnight prior to analysis. Isotope ratios for $\mathrm{N}$ and $\mathrm{C}$ are presented in delta notation, with per mille (\%o) units relative to isotopic reference standards, where $\delta=1000\left[\left(R_{\text {sample }} / R_{\text {standard }}\right)-1\right]$, and $R={ }^{15} \mathrm{~N} /{ }^{14} \mathrm{~N}$ and ${ }^{13} \mathrm{C} /$ ${ }^{12} \mathrm{C}$, for $\delta^{15} \mathrm{~N}$ and $\delta^{13} \mathrm{C}$, respectively. The isotopic reference standards are atmospheric $\mathrm{N}_{2}$ for $\delta^{15} \mathrm{~N}$, and ViennaPeeDee Belemnite for $\delta^{13} \mathrm{C}$. Isotopic measurements were made on ca. 0.75-mg hair samples using an ECS 4010 elemental analyzer (Costech Analytical Technologies, Valencia, CA, USA) operating with continuous flow to a Finnigan Delta Plus XL mass spectrometer (Thermo Scientific, Waltham, MA, USA). The precision of the isotopic analyses was determined to be $\pm 0.2 \%$ for both $\delta^{15} \mathrm{~N}$ and $\delta^{13} \mathrm{C}$, based on replicate analyses of acetanilide, ammoniumsulfate, sodiumnitrate, glycine, polyethylene foil, geophysical gel and NBS-22 reference materials.

The $\mathrm{Hg}$ concentration analyses were performed in the Department of Geological Sciences, University of Michigan. Prior to analysis ca. 1-mg samples were shaken for $3 \mathrm{~h}$ in $1 \%$ RBS-35 detergent (Thermo Scientific), and rinsed three times in deionized water to clean the hair of possible external contamination. Samples were then dried overnight in a clean box with desiccant, and weighed into Teflon digestion vessels. Concentrated $\mathrm{HNO}_{3}$ and $\mathrm{H}_{2} \mathrm{O}_{2}$ were added to the vessels, and samples were completely digested in a closed-system microwave digestion apparatus. After cooling in a water bath, the vessels were opened and solutions were diluted with deionized water. Certified reference materials (CRMs) and reagent blanks were digested with each batch of eight samples, and most samples were digested in duplicate for quality control. Samples were analysed for total $\mathrm{Hg}$ by cold-vapour atomic absorption spectroscopy $(\lambda=$ $253.7 \mathrm{~nm})$, using an automated MA-2 $\mathrm{Hg}$ analyser (Nippon Instruments, College Station, TX, USA). The $\mathrm{Hg}^{2+}$ in solution was reduced by $\mathrm{SnCl}_{2}$ to $\mathrm{Hg}^{0}$, concentrated on a gold trap and then released by heating for analysis. Concentration curves spanning the analytical range were established each day, with coefficient of determination $\left(r^{2}\right)$ values of 0.999 or better, and check standards and replicate samples were run after every eighth sample. The limit of detection was $0.2 \mathrm{ng} \mathrm{L}^{-1}$ (well below all sample solution concentrations) and the analytical uncertainty was $\pm 5 \%$, as verified by analyses of CRM-397 (Bureau Communautaire de Références [BCR] human hair; Quevauviller et al. 1992) and replicate analyses.

\section{Results}

The stable isotopic results (Fig. 2; Table 1) show a greater range in polar bear hair $\delta^{13} \mathrm{C}$ (from $-17.5 \%$ to $-13.0 \%$ ) and $\delta^{15} \mathrm{~N}$ values (from $18.2 \%$ to $23.5 \%$ ) than are found in the published polar bear muscle analyses (Ramsay $\&$ 


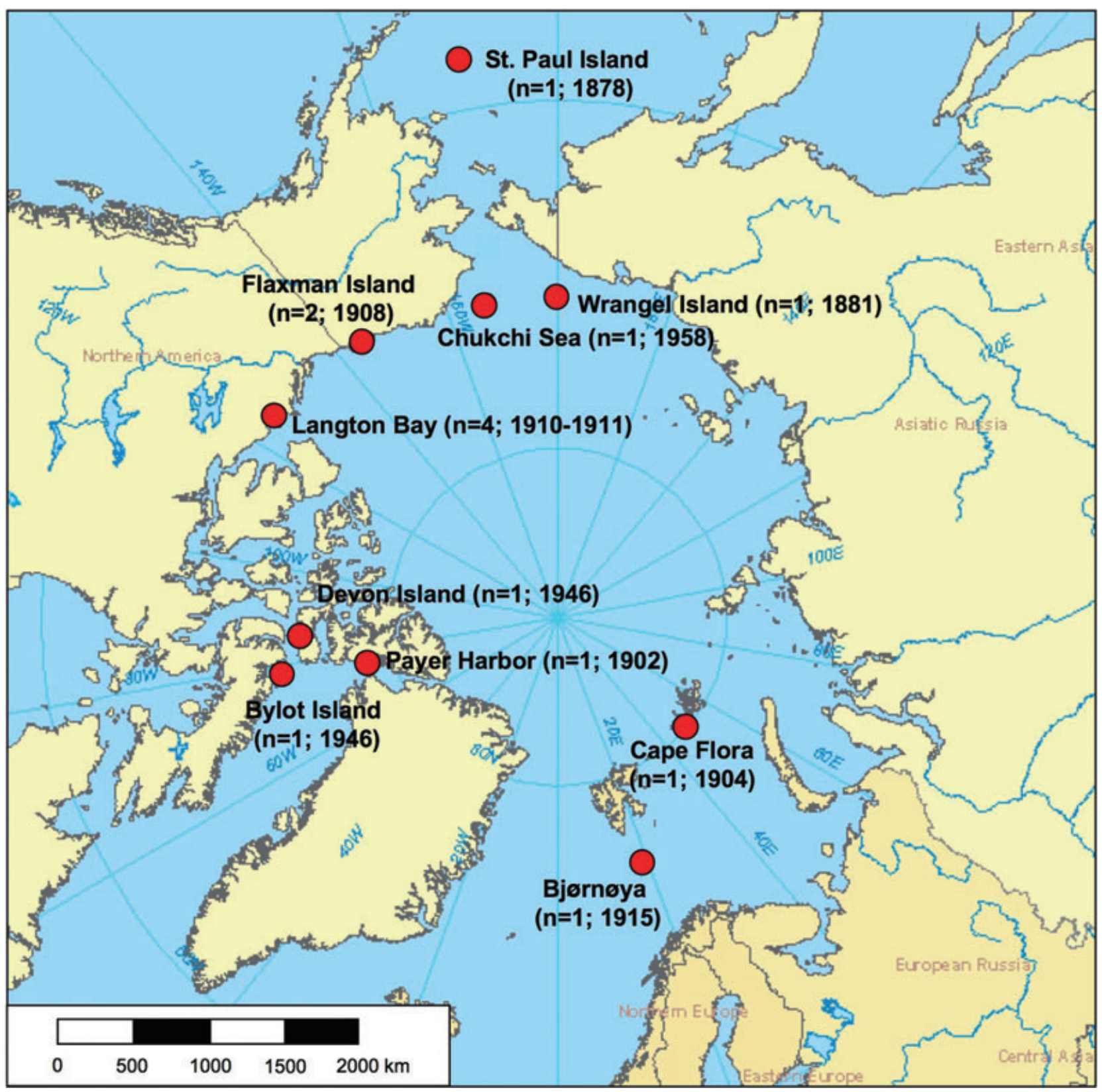

Fig. 1 Map showing the collection locations, number of specimens and year of collection, as recorded in the museum catalogues. The specific collection locations were only recorded for 14 of the 26 samples analysed. See Table 1 for all of the available sample information.

Hobson 1991; Hobson \& Welch 1992; Atwell et al. 1998). The mean $\delta^{13} \mathrm{C}$ value is $-15.3 \%$ ( $1.1 \%$ SD) and the mean $\delta^{15} \mathrm{~N}$ value is $20.5 \%$ ( $1.4 \%$ SD) for the 26 specimens analysed. The mean polar bear hair $\delta^{15} \mathrm{~N}$ value reported here agrees well with previously published polar bear muscle $\delta^{15} \mathrm{~N}$ values for Lancaster Sound, NT, Canada. Hobson \& Welch (1992) reported a mean of $21.1 \%$ and an SD of $0.6 \%$ o $(n=3)$. Atwell et al. (1998) reported a mean of $19.6 \%$ and an SE of $0.5 \%$ $(n=5)$. However, the $\delta^{13} \mathrm{C}$ values reported here are significantly different (one-way ANOvA, $p<0.0001$ ) than previously published $\delta^{13} \mathrm{C}$ values for polar bear muscle samples collected from Eskimo Point, NT, Canada, which range between $-16.6 \%$ and $-18.3 \%$ (mean $-17.7 \%$, SD $0.2 \%$, $n=12$; Ramsay \& Hobson 1991), and similar samples from Lancaster Sound, which exhibit a mean $\delta^{13} \mathrm{C}$ value of $-18.0 \%$ (SD $0.6 \%, n=3$; Hobson \& Welch $1992)$. 


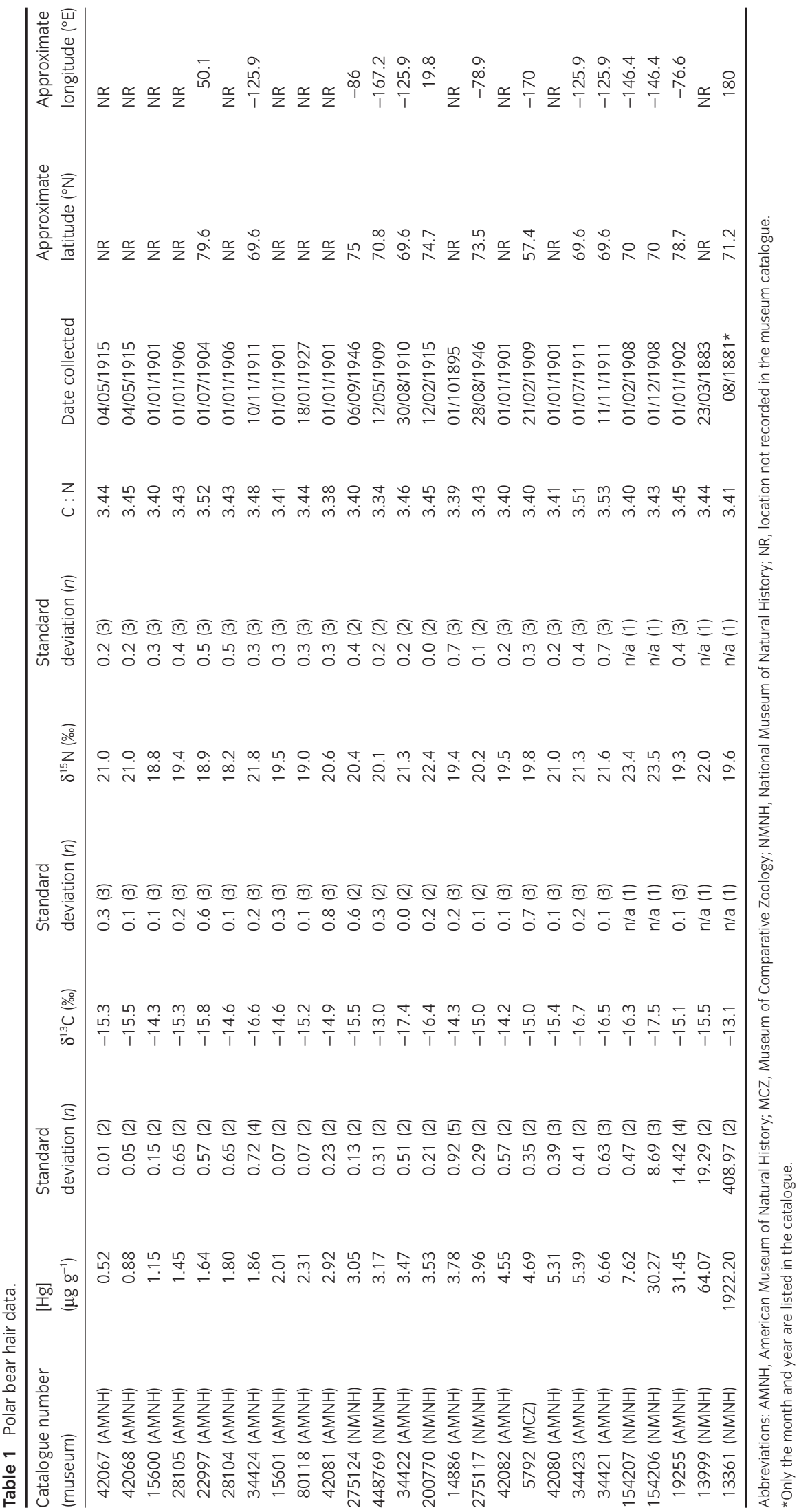




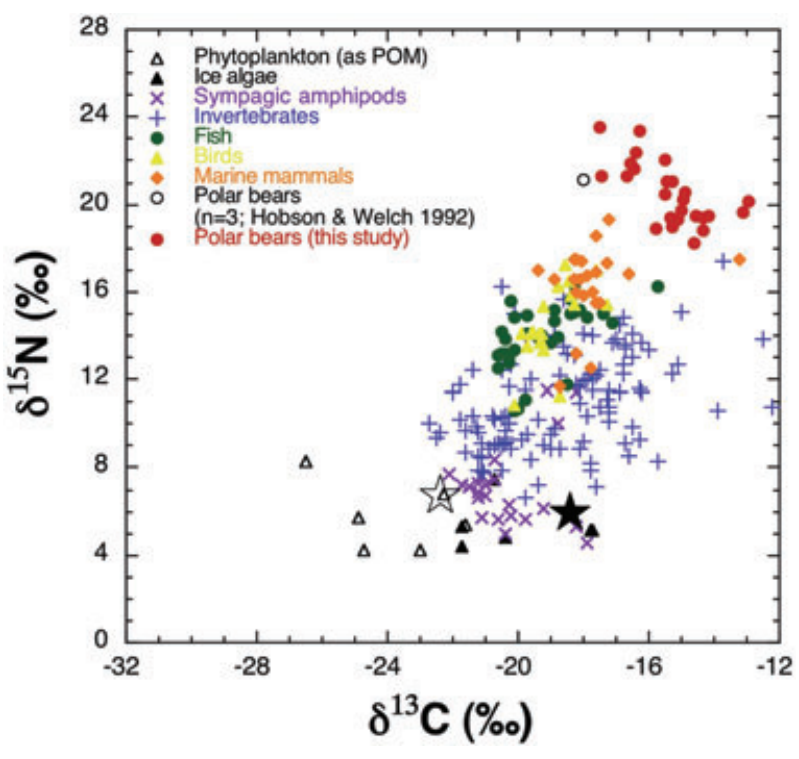

Fig. $2 \delta^{15} \mathrm{~N}$ versus $\delta^{13} \mathrm{C}$ values for Arctic faunal tissues. The open black star represents the average value for phytoplankton (as particulate organic matter); the solid black star represents the average ice algae values described in the text. The sources of data as as follows: phytoplankton (Hobson \& Welch 1992; Hobson et al. 2002; Tamelander et al. 2006; Tremblay et al. 2006); ice algae (Hobson \& Welch 1992; Hobson et al. 2002; Campbell et al. 2005; Tamelander et al. 2006; Tremblay et al. 2006); sympagic amphipods (Tremblay et al. 2006); invertebrates (Hobson \& Welch 1992; Hobson et al. 2002; Campbell et al. 2005; Tamelander et al. 2006); birds (Hobson \& Welch 1992; Hobson et al. 2002; Tremblay et al. 2006); fish (Hobson \& Welch 1992; Hobson et al. 2002; Kurle 2002; Campbell et al. 2005; Tamelander et al. 2006); marine mammals (Hobson \& Welch 1992; Muir et al. 1995; Hobson et al. 1997; Hobson et al. 2002; Kurle 2002; Campbell et al. 2005; Outridge, Hobson et al. 2005). All of the previously published data were determined for vertebrate muscle tissue and invertebrate whole-body homogenates.

Most hair samples were analysed in triplicate for both $\delta^{13} \mathrm{C}$ and $\delta^{15} \mathrm{~N}$, with some samples exhibiting intraspecimen variability (reported as the SD of triplicate analyses; Table 1) in excess of the reported analytical error of $0.2 \%$. However, the intraspecimen variability in polar bear hair isotopic compositions is approximately an order of magnitude lower than the total range in hair $\delta^{13} \mathrm{C}$ and $\delta^{15} \mathrm{~N}$ values observed in the sample set, suggesting that the large range in isotopic compositions across all specimens is most likely to result from differences in the ecosystem conditions, such as the isotopic composition of primary producers and local food-web structure, rather than individual feeding behaviours.

The total $\left[\mathrm{Hg}\right.$ ] ranges between 0.52 and $7.62 \mu \mathrm{g} \mathrm{g}^{-1}$ for 22 of the 26 wild polar bear hair specimens investigated, with a mean concentration of $3.26 \mu \mathrm{g} \mathrm{g}^{-1}$ (SD $1.9 \mu \mathrm{g} \mathrm{g}^{-1}$; Table 1). Four specimens exhibited an anomalously high [Hg] $\left(>30 \mu \mathrm{g} \mathrm{g}^{-1}\right)$, with high intraspecimen variability among triplicate analyses $\left(\mathrm{SD}>8.69 \mu \mathrm{g} \mathrm{g}^{-1}\right)$. Although none of the museum catalogues explicitly denote information regarding preservative applications, these four samples may have been exposed to mercuric chloride (which was sometimes used as a specimen preservative in the late 1800s and early 1900s) during sampling, museum cataloguing or subsequent storage. As these four specimens are statistical outliers, being more than 13 standard deviations above the mean, we do not consider them in our $[\mathrm{Hg}]$ data interpretations. Intraspecimen [Hg] variability for the 22 samples considered in our analysis range between 0.01 and $0.92 \mu \mathrm{g} \mathrm{g}^{-1}$ (reported as the standard deviation of duplicate or triplicate analyses; Table 1).

\section{Discussion}

In order to accurately interpret relationships among historic polar bear hair stable isotope and $\mathrm{Hg}$ concentration data, similar data for other Arctic marine organisms lower in the food chain is required, as both the isotopic composition and $\mathrm{Hg}$ concentration of biologic materials depend upon trophic position, food-web structure and feeding behaviour. However, the general lack of historic (pre-1950) stable isotope and Hg concentration data for most Arctic marine organisms, and the limited availability of suitable specimens for such analyses, present immediate challenges to such research. In an effort to overcome these limitations, we have compiled both modern (post1980) and historic (pre-1950) data available from the literature for a variety of organisms from a variety of high-latitude locations. All previously published data is cited in the following discussion, and in the accompanying figures, where appropriate.

It is important to consider the fundamental limitations that the temporal and geographic heterogeneity of the presented data impose on our interpretations. Given the geographic heterogeneity of the polar bear hair data we present, all interpretations are relevant only on broad regional scales. Previous research has demonstrated that complex relationships between food-web channels exist on spatial scales of less than $100 \mathrm{~km}$ (Tamelander et al. 2006), whereas $\delta^{13} \mathrm{C}$ values of marine invertebrates are known to vary by ca. $2-4 \%$ between the Bering/Chukchi and Beaufort/Arctic Ocean regions (Schell et al. 1998). With respect to Hg, Eaton \& Farant (1982) reported polar bear hair concentrations in the western Canadian Arctic (Amundsen Gulf) that are approximately 10 ppm higher than in the central and eastern Canadian Arctic, for samples collected between 1977 and 1980. Specimen location data are available for only 11 of the 22 polar bear hair samples discussed below (Table 1). Given this low sample size, and the resultant low spatial sample density, geographic effects are beyond the scope of this study. For a comprehensive review of spatial and temporal trends in 
$\mathrm{Hg}$ concentrations determined for various Arctic marine biota, see Braune et al. (2005).

Similarly, the temporal heterogeneity, limited sample size and lack of biophysical data (including age, collection season, sex and sexual maturity/reproductive status) in our data set precludes robust interpretation of time-dependent changes in food-web structures, $\mathrm{Hg}$ deposition/uptake rates, biophysical effects and biomagnification trends through time. However, the data do allow us to interpret gross regional-scale relationships between food-web structure and the fate and transport of $\mathrm{Hg}$ through a composite high-latitude food web, irrespective of space and time. As a result of these important limitations, our discussion centres on the interpretation of regional food-web structure based on the $\delta^{13} \mathrm{C}$ and $\delta^{15} \mathrm{~N}$ data, and the relationships between the composite highlatitude food-web structure and the $\mathrm{Hg}$ concentrations found in polar bear hair.

\section{Stable isotopes}

The stable isotopic assessments of food-web structure are based on the enrichment of ${ }^{15} \mathrm{~N}$ and ${ }^{13} \mathrm{C}$ in consumer tissues, relative to diet. These fractionations are more pronounced for nitrogen $\left(\delta^{15} \mathrm{~N}_{\text {consumer }}-\delta^{15} \mathrm{~N}_{\text {diet }} \approx 2-4 \%\right.$ o $)$ than for carbon $\left(\delta^{13} \mathrm{C}_{\text {consumer }}-\delta^{13} \mathrm{C}_{\text {diet }} \approx 0-2 \%\right.$ ) , suggesting that the nitrogen isotopic composition is directly related to the trophic position of an organism, and that the carbon isotopic composition reflects the carbon source at the base of the food web (Kelly 2000).

\section{Carbon}

The $4.4 \%$ range in hair $\delta^{13} \mathrm{C}$ values reported here suggests that polar bears participate in food webs with a similarly wide range in primary producer carbon isotope compositions. Previous research by Hilderbrand et al. (1996) indicates that the isotopic composition of American black bear (Ursus americanus) hair and muscle tissues are not significantly different when fed the same diet over a seven-month period; assuming the same relationship exists in polar bears, the significant difference between polar bear hair (this study) and muscle (Ramsay $\delta$ Hobson 1991; Hobson \& Welch 1992) $\delta^{13} \mathrm{C}$ values described above, supports the interpretation that the carbon isotope composition of primary producers differs by several per mille (ca. 4-5\%)across the Arctic.

Primary production in Arctic ecosystems occurs predominantly in phytoplankton and ice algae in pelagic and sympagic environments, respectively. Bradstreet \& Cross (1982) reported on the importance of the sympagic ice algae community to Arctic food webs, and Welch (1992) suggested that sympagic primary production accounts for ca. $10 \%$ of total primary production in the $98000-\mathrm{km}^{2}$ Lancaster Sound region. Two recent investigations report on the carbon isotope composition of phytoplankton, as particulate organic matter, and ice algae in Arctic systems, with both investigations finding that ice-associated particulate organic matter exhibits $\delta^{13} \mathrm{C}$ values approximately 3-10\% more positive than pelagic organic matter (Tamelander et al. 2006; Tremblay et al. 2006). The compiled primary producer data presented in Fig. 2 further supports this finding.

The previously published primary producer data presented in Fig. 2 represent 76 phytoplankton (as particulate organic matter) and 43 ice algae samples collected from the Barents Sea (Tamelander et al. 2006), North Water Polynya (Hobson et al. 2002; Tremblay et al. 2006), and Barrow Strait-Lancaster Sound (Hobson \& Welch 1992). The carbon isotope compositions of Arctic phytoplankton and ice algae are significantly different (one-way ANOvA, $p<0.0001$ ), with phytoplankton exhibiting an average $\delta^{13} \mathrm{C}$ value of $-22.4 \%$ (SD $1.1 \%$, $n=76)$, and with ice algae exhibiting an average $\delta^{13} \mathrm{C}$ value of $-18.4 \%$ (SD $4.2 \%$ o, $n=43$ ). The ca. $4 \%$ difference in mean phytoplankton and ice algae primary producer $\delta^{13} \mathrm{C}$ values, and $4.4 \%$ range in polar bear hair $\delta^{13} \mathrm{C}$ values reported here (Fig. 2), suggests polar bears derive nutrition from both of these pelagic and sympagic primary producers (i.e., phytoplankton with relatively low $\delta^{13} \mathrm{C}$ values and ice algae with relatively high $\delta^{13} \mathrm{C}$ values).

Given that sea ice represents the primary seal hunting habitat for polar bears, and that sympagic food-web channels are an important component of Arctic ecosystems (Bradstreet \& Cross 1982; Welch 1992), it is not surprising that the carbon isotope composition of polar bear hairs reflects carbon fixation occurring in ice-associated environments. However, the distribution of the polar bear hair $\delta^{13} \mathrm{C}$ values presented in Fig. 2 suggests that polar bears derive nutrition from coupled pelagic and sympagic carbon sources, rather than from discrete primary production end members.

Alternative explanations are also possible. Ice algae $\delta^{13} \mathrm{C}$ values demonstrate a strong correlation with ice thickness in both Antarctic (Arrigo et al. 2003) and Arctic (Tremblay et al. 2006) systems, potentially explaining the high variability in the reported ice algae $\delta^{13} \mathrm{C}$ values (e.g., Tamelander et al. 2006), and ultimately contributing to the variability in polar bear hair carbon isotope compositions. Additionally, benthic organisms also exhibit more positive $\delta^{13} \mathrm{C}$ values relative to pelagic organisms (Hobson et al. 2002). It is therefore not possible to differentiate between sympagic and benthic food-web components, based on carbon isotopic composition alone. Relatively positive benthic organism $\delta^{13} \mathrm{C}$ values may result from the greater uptake of organic carbon derived from ${ }^{13} \mathrm{C}$ - 
enriched ice algae than of relatively ${ }^{13} \mathrm{C}$-depleted pelagic particulate organic matter (Hobson et al. 2002). In fact, recent research suggests some Arctic benthic species may preferentially consume ice algae, rather than phytoplankton, because of the higher essential fatty acid content of ice algae (McMahon et al. 2006). Given the significant difference in pelagic versus sympagic primary producer $\delta^{13} \mathrm{C}$ values, similarities in the range of $\delta^{13} \mathrm{C}$ values observed at all trophic positions, and the polar bears' biological reliance on sympagic environments, we suggest that the previously undocumented range in polar bear hair $\delta^{13} \mathrm{C}$ values reported here results from the coupling of pelagic and sympagic food-web channels in Arctic ecosystems (Fig. 2).

\section{Nitrogen}

The 5.3\%o range in polar bear hair $\delta^{15} \mathrm{~N}$ values reported here (Fig. 2; Table 1) exceeds the range in polar bear tissue values recognized in earlier studies (Hobson \& Welch 1992; Atwell et al. 1998). Arctic pelagic $(6.7 \pm 0.6 \%$ SD, $n=76)$ and sympagic (5.6 $\pm 1.0 \%$ o SD, $n=43)$ primary producers have similar $\delta^{15} \mathrm{~N}$ values (Hobson \& Welch 1992; Hobson et al. 2002; Campbell et al. 2005; Tamelander et al. 2006; Tremblay et al. 2006), suggesting that trophic position, rather than the source of primary production, is the main control on polar bear tissue nitrogen isotope compositions. Empirical and experimental data sets indicate bear tissues show a 3.2$4.1 \%$ increase in $\delta^{15} \mathrm{~N}$ values relative to diet (Hobson $\delta$ Welch 1992; Hilderbrand et al. 1996; Hobson et al. 2002). Assuming a nitrogen isotope fractionation of 3.8\% per trophic level (as used in Hobson et al. 2002), and an average primary producer $\delta^{15} \mathrm{~N}$ value of $6.3 \%$ (calculated from the primary producer data presented in Fig. 2), our results indicate polar bears occupy the 4.1-5.5-level trophic positions, in good agreement with previous stable isotope-based results (Hobson et al. 2002) and known trophic relationships (Bradstreet \& Cross 1982).

The polar bear hair stable isotopic data presented here advances our understanding of food-web structure in high-latitude ecosystems. As described above, the carbon isotope composition of polar bear hair suggests these top predators ultimately derive nutrition from mixed pelagic and sympagic primary producers, and associated foodweb channels, at the regional scale. Given the association of polar bears with sympagic habitats, and the opportunistic feeding behaviour of the polar bears' preferred diet (ringed seals, Pusa hispida), this interpretation is intuitively plausible, if not expected. Yet, the only polar bear stable isotopic data available in the literature (Ramsay $\&$ Hobson 1991; Hobson \& Welch 1992; Hobson et al. 2002) suggests that polar bears derive nutrition solely from pelagic food-web channels (Hobson et al. 2002: fig. 1)in contrast to the data and interpretations presented here. This is an important contribution of the current research, as recent studies suggest the Arctic is a significant sink in the global Hg cycle: thus, interpreting the stable isotopic data presented above, in concert with $\mathrm{Hg}$ concentration data, provides a novel opportunity to evaluate the fate and transport of $\mathrm{Hg}$ through high-latitude food webs and food-web channels.

\section{Mercury concentrations}

Highly elevated concentrations of $\mathrm{Hg}$ are observed in modern Arctic snow during springtime tropospheric Hg-depletion events (Lu et al. 2001). These events result from the rapid oxidation of globally transported gaseous elemental $\mathrm{Hg}$, and are believed to be exacerbated by atmospheric $\mathrm{Br}$ and $\mathrm{BrO}$ derived from sea-salt aerosols (Lu et al. 2001; Ariya et al. 2004). The accumulation of $\mathrm{Hg}$ in high-latitude Northern Hemisphere systems has increased between pre-industrial and modern times, with the significant anthropogenic increase of atmospheric $\mathrm{Hg}$ deposition occurring in the second half of the 20th century (Schuster et al. 2002; Fitzgerald et al. 2005; Outridge, Stern et al. 2005). In an effort to limit temporal effects on our interpretations, we restricted our sample set to polar bear hair specimens collected prior to 1950 . Our polar bear hair Hg concentration data agree well with similar published data for 18 samples collected between 1910 and 1927, from the Canadian Arctic and Hudson's Bay (Eaton \& Farant 1982; Fig. 3).

Elevated $\mathrm{Hg}$ concentrations have been identified in a variety of Arctic fauna across geographically and temporally heterogeneous scales, including a number of marine mammals and birds (Eaton \& Farant 1982; Wagemann et al. 1996; Atwell et al. 1998; Outridge, Hobson et al. 2005; Dietz, Riget, Boertmann et al. 2006; Dietz, Riget, Born et al. 2006). Previous research indicates Hg biomagnification occurs in Arctic food webs via uptake by primary producers and subsequent consumption by invertebrates, fish, birds and marine mammals (Atwell et al. 1998). However, it is important to note that polar bears did not fit this published biomagnification trend, and that they were the only species to exhibit lower $\mathrm{Hg}$ concentrations than their prey (Atwell et al. 1998). Atwell et al. suggested that this exception was most likely to have resulted from individual feeding behaviours, whereby polar bears limit their exposure to the available $\mathrm{Hg}$ through preferential consumption of seal skin and adipose tissue (Norstrom et al. 1986), both of which have been shown to exhibit lower $\mathrm{Hg}$ concentration than muscle and organs (Smith \& Armstrong 1975). Our results for polar bear hair support this interpretation, demonstrating low 


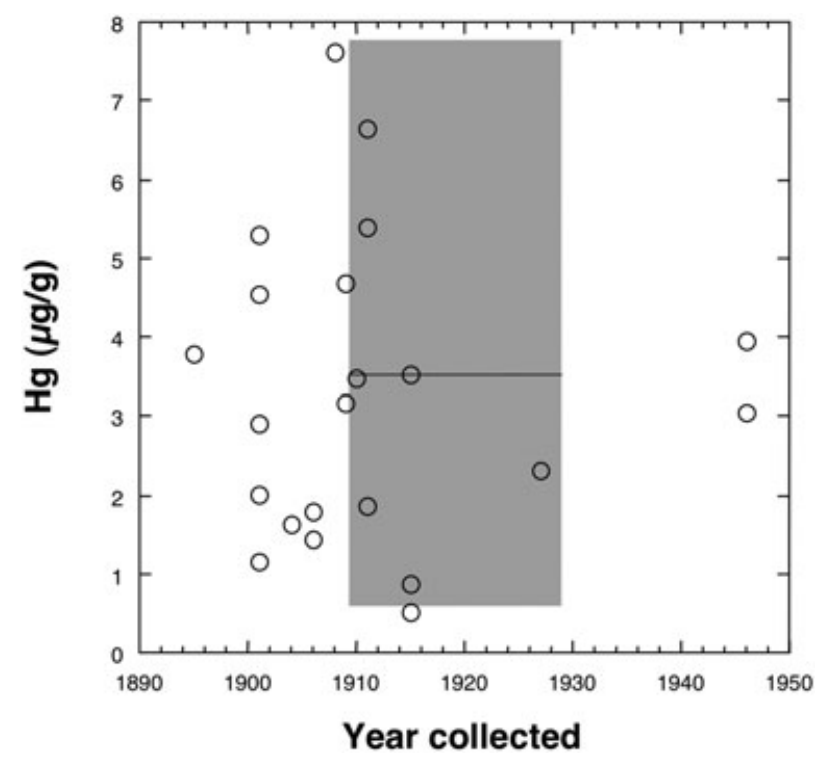

Fig. $3 \mathrm{Hg}$ concentration versus year of sample collection for all samples with recorded collection locations and ages. The circles represent the values for polar bear hair specimens from this study; the shaded grey area shows the total range and the mean (solid line) in organic [Hg] determined for 18 previously published polar bear hair specimens (Eaton \& Farant 1982).

$\mathrm{Hg}$ concentrations $\left(<1.0 \mu \mathrm{g} \mathrm{g}^{-1}\right)$ in some individuals with relatively high $\delta^{15} \mathrm{~N}$ values $(20-21 \%$ o)

\section{Mercury biomagnification}

The slope of the regression of log-transformed Hg concentrations versus $\delta^{15} \mathrm{~N}$ represents a quantification of the $\mathrm{Hg}$ biomagnification power for a composite post-1980 high-latitude food web (Fig. 4a). We present our polar bear hair data alongside compiled $[\mathrm{Hg}]$ and $\delta^{15} \mathrm{~N}$ tissue data for a variety of marine fauna collected during the late 19th, early 20th and late 20th centuries (Eaton \& Farant 1982; Applequist et al. 1985; Atwell et al. 1998; Campbell et al. 2005; Outridge, Hobson et al. 2005; Dietz, Riget, Boertmann et al. 2006). The Hg biomagnification power of the composite post-1980 high-latitude food web is 0.17 . This composite value is intermediate to the total $\mathrm{Hg}$ biomagnification power of 0.20 calculated for both the Lancaster Sound and Northwater Polynya food webs (Atwell et al. 1998; Campbell et al. 2005), and the biomagnification power of 0.15 (i.e., a biomagnification factor of 1.40) that has been determined for the Alaskan Arctic (Dehn et al. 2006). The 95\% confidence limit of the linear regression of $\log [\mathrm{Hg}]$ versus $\delta^{15} \mathrm{~N}$ in the post-1980 samples encompasses $\mathrm{Hg}$ biomagnification powers (i.e., regression line slopes) ranging between 0.12 and 0.22 (Fig. 4a). A similar biomagnification trend is apparent in a limited pre-1950 data set (Fig. 4b), including polar bears, beluga (Delphinapterus leucas), black guillemots (Cepphus grylle) and white-tailed eagles (Haliaeetus albicilla) (Eaton \& Farant 1982; Applequist et al. 1985; Outridge, Hobson et al. 2005; Dietz, Riget, Boertmann et al. 2006; this study). In contrast to previous research (Atwell et al. 1998), the data presented here suggest that $\mathrm{Hg}$ biomagnification was, and likely remains, a common process affecting most polar bears throughout the Arctic.

\section{Mercury transport pathways}

The interpretation of this biomagnification trend in the context provided by stable isotope-based assessments of food-web structure informs our understanding of the $\mathrm{Hg}$ transport pathways in high-latitude ecosystems. Based on compound-specific $\delta^{13} \mathrm{C}$ values determined for consumers, and both sympagic and pelagic primary producers, Budge et al. (2008) suggest ice algae are likely to account for $24-71 \%$ of the fatty acid material in Arctic consumers near Barrow, Alaska. Other research has found that sympagic primary production accounts for ca. 57\% of total primary production in the central Arctic Ocean, but less than $5 \%$ in the central Chukchi Sea (Gosselin et al. 1997). Such variability in the balance between pelagic and sympagic primary production is likely to contribute to the geographic variability observed in the isotopic compositions of Arctic biota (e.g., Dietz et al. 1996; Wagemann et al. 1996; Schell et al. 1998; Dehn et al. 2005), and, as a result, would also be expected to affect $\mathrm{Hg}$ transport through sympagic versus pelagic food-web end members.

The stable isotope data presented here indicate that polar bears participating in food webs dominated by pelagic organisms tend to have more positive $\delta^{15} \mathrm{~N}$ and more negative $\delta^{13} \mathrm{C}$ values, than polar bears exploiting sympagic food-web channels (Fig. 2). These pelagic polar bears exhibit the highest $\delta^{15} \mathrm{~N}$ values and $\mathrm{Hg}$ concentrations (Fig. 5b), whereas sympagic polar bears exhibit the highest $\delta^{13} \mathrm{C}$ values, and the lowest $\delta^{15} \mathrm{~N}$ values and $\mathrm{Hg}$ concentrations (Figs. 2, 5). Several ecological explanations for these relationships are possible.

High-latitude pelagic food webs may be more complex than sympagic food webs, resulting in higher trophic positions (i.e., higher $\delta^{15} \mathrm{~N}$ values) and increased potential for $\mathrm{Hg}$ biomagnification in the pelagic top predators. The fundamental difference between high-latitude seasonally ice-free and perennially ice-covered ecosystems is that seasonally ice-free ecosystems are often nutrient limited, whereas perennially ice-covered ecosystems are generally light limited (Smetacek \& Nicol 2005). Furthermore, the epipelagic copepod community composition and biomass varies with regional primary productivity (Atkinson 

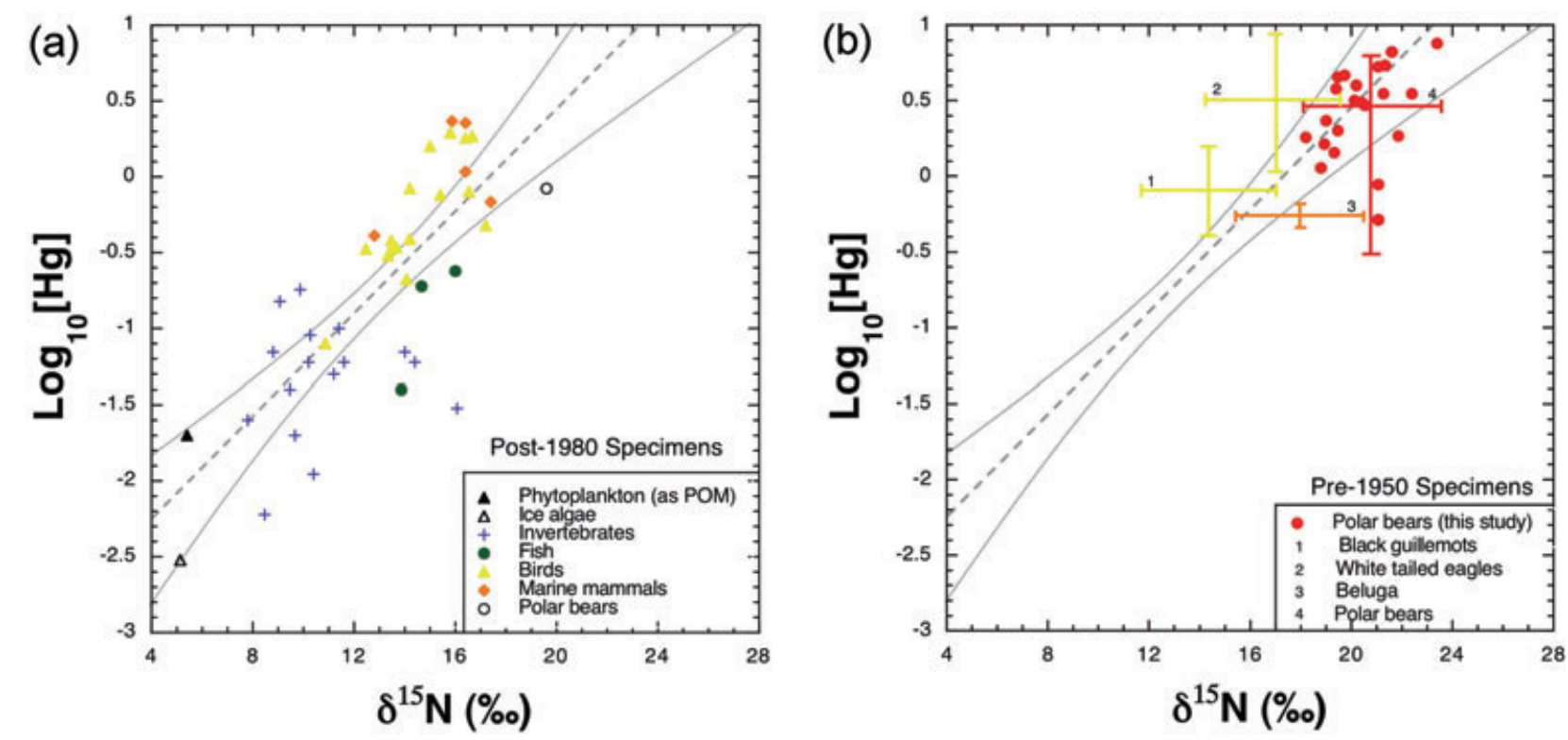

Fig. 4 Variation of $\log _{10}[\mathrm{Hg}]$ with $\delta^{15} \mathrm{~N}$ in Arctic faunal tissues for (a) previously published post-1980 specimens, and for (b) original and previously published pre-1950 specimens. The dashed line in (a) represents the composite mercury biomagnifcation trend in post-1980 specimens (data from Atwell et al. 1998 and Campbell et al. 2005). The grey curves correspond to the $95 \%$ confidence limit of the least-squares regression line plotted in (a). We include the post-1980 regression line and confidence limits in (b) to aid comparisons of the data. The red circles (pre-1950 polar bear hairs) in (b) represent data original to this study. The whisker plots numbered 1-4 in (b) present the range in published pre-1950 mercury concentrations for (1) black guillemot (Cepphus grylle) feathers (Applequist et al. 1985), (2) white-tailed eagle (Haliaeetus albicilla) feathers (range in mean values of Dietz, Riget, Boertmann et al. 2006), (3) beluga (Delphinapterus leucas) muscle (range in geometric mean values of Outridge, Hobson et al. 2005) and (4) polar bear (Ursus maritimus) hairs (Eaton \& Farant 1982). The range in $\delta^{15} \mathrm{~N}$ values for guillemots and eagles are estimated based on the post-1980 isotopic composition of each species' diet, and the expected nitrogen isotope fractionation of 3.8\% per trophic level. The range in beluga $\delta^{15} \mathrm{~N}$ values corresponds to the range in $\delta^{15} \mathrm{~N}$ values from teeth, reported by Outridge, Stern et al. (2005). And the range in polar bear hair $\delta^{15} \mathrm{~N}$ values reported by Eaton \& Farant (1982) is assumed to be equivalent to the range in polar bear hair $\delta^{15} \mathrm{~N}$ values reported in the current study.
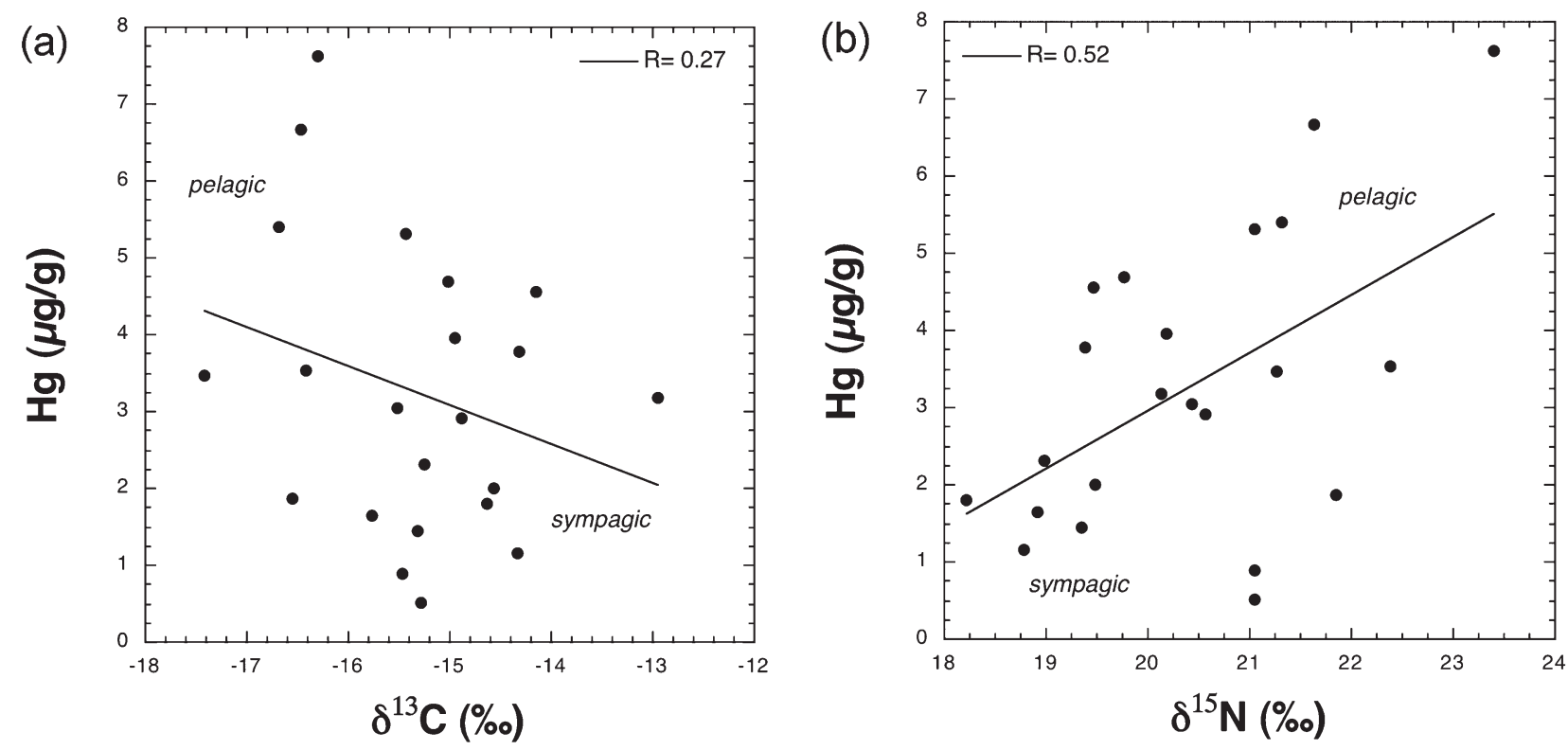

Fig. 5 Variation of $[\mathrm{Hg}]$ with (a) $\delta^{13} \mathrm{C}$ and (b) $\delta^{15} \mathrm{~N}$ in pre-1950 polar bear hairs. The two-tailed $p$ value is 0.2243 and 0.0131 for the least squares regression lines presented in (a) and (b), respectively. 
1998), suggesting that fundamental differences in trophic structure between the more productive pelagic and relatively less productive sympagic systems are to be expected. Direct observation of ice-associated organism stomach contents indicate that the sympagic food webs progress from ice algae, to copepods and amphipods, to Arctic cod (Arctogadus glacialis), to ringed seals, which are the primary food source for polar bears (Bradstreet $\delta$ Cross 1982). More complex predator-prey relationships, particularly for organisms eating species that are low on the food chain, may exist in pelagic food webs, as suggested by the higher trophic positions (based on more positive $\delta^{15} \mathrm{~N}$ values) of pelagic amphipods compared with sympagic amphipods (Tamelander et al. 2006). Longer pelagic food chains would ultimately result in more than five trophic levels, and in higher $\mathrm{Hg}$ concentrations in polar bears taking advantage of predominantly pelagic, rather than sympagic, food-web channels.

High $\mathrm{Hg}$ concentrations in polar bear hair may also result from the circumstantial consumption of prey tissues that are relatively enriched in bioavailable organic Hg. Polar bears primarily feed on ringed seals, the most common and best-adapted Arctic seal (Wagemann et al. 1996), although recent research indicates bowhead whales (Balaena mysticetus) represent ca. 19\% of the polar bear winter diet in the southern Beaufort Sea (Bentzen et al. 2007). The total $\mathrm{Hg}$ concentrations in ringed seal livers are between one and two orders of magnitude higher than the concentrations found in muscle, and about one order of magnitude higher than the concentrations found in kidneys (Wagemann et al. 1996; Dehn et al. 2005), and similar relationships are recognized in belugas and narwhals (Monodon monoceros), both of which are less common polar bear prey species (Wagemann et al. 1998). However, Arctic marine mammal livers and muscle exhibit similar methylmercury ( $\mathrm{MeHg}$ ) concentrations (mean concentrations of ca. $1-2 \mu \mathrm{g} \mathrm{g}^{-1}$; Wagemann et al. 1998), whereas the mean values of $\mathrm{MeHg}$ concentrations in the skin from the same individuals are in the range of $0.53-0.69 \mu \mathrm{g} \mathrm{g}^{-1}$. Total $\mathrm{Hg}$ in blubber from the same individuals range between mean values of 0.04 and $0.1 \mu \mathrm{g} \mathrm{g}^{-1}$. Thus, preferential feeding on marine mammal adipose tissue may limit $\mathrm{Hg}$ ingestion by polar bears at the same time as decreasing the ${ }^{13} \mathrm{C}$ content of polar bear tissues, as lipid-rich diets have lower $\delta^{13} \mathrm{C}$ values than non-lipid diets (Hilderbrand et al. 1996). Such feeding behaviours are likely to complicate the relationship between $\mathrm{Hg}$ concentrations and $\delta^{13} \mathrm{C}$ values in sympagic and pelagic polar bear hairs (Fig. 5a). However, bears unable to preferentially consume adipose tissue because of environmental pressures and/or nutritional requirements may ingest significantly more $\mathrm{Hg}$ if muscle and internal organs are consumed.
Perennial sea-ice may limit $\mathrm{Hg}$ availability to sympagic food webs. A dramatic increase in the $\mathrm{Hg}$ concentrations of snow deposited on Arctic sea ice occurs between winter and spring (Lu et al. 2001) as a result of Arctic Hg depletion events (Ariya et al. 2004; Douglas et al. 2008), and spring meltwaters add some of this oxidized $\mathrm{Hg}$ to Arctic ecosystems. However, the photoreduction of oxidized $\mathrm{Hg}$ from the surface snow pack returns much of the $\mathrm{Hg}$ deposited in snow to the atmosphere (Ariya et al. 2004). This suggests that the accumulation of Hg in Arctic systems occurs during the spring primary productivity blooms, which are contemporaneous with halogendriven $\mathrm{Hg}$ oxidation events and rapid meltwater transport of oxidized $\mathrm{Hg}$ compounds into marine environments. Ecosystems associated with perennial sea ice may experience less $\mathrm{Hg}$ accumulation because of the limited transport of oxidized $\mathrm{Hg}$ compounds through the pack ice, as well as the more pronounced photoreduction of oxidized $\mathrm{Hg}$ compounds in surface snow (Ariya et al. 2004). In contrast, epipelagic ecosystems may be more susceptible to $\mathrm{Hg}$ bioavailability because of increased $\mathrm{Hg}$ oxidation at higher salinities (Poulain et al. 2007).

\section{Conclusions}

Our results suggest that pre-1950 polar bears derived nutrition from a combination of pelagic and sympagic food-web channels, and that Hg concentrations tend to be higher in pelagic food-web participants. The variability of $\mathrm{Hg}$ concentrations in polar bear hair specimens collected before 1950 is likely to have resulted from a combination of trophic structure, feeding behaviour and perennial seaice effects, although given the limited size and geographic heterogeneity of our data set, unrecognized spatial and temporal mechanisms are also likely. The elevated $[\mathrm{Hg}]$ in polar bear hair in more recent times (e.g., Dietz, Riget, Born et al. 2006) is probably related to the increased atmospheric deposition of anthropogenic $\mathrm{Hg}$, and may be spatially distributed, although this has not yet been adequately tested. The relationships between the regional food-web structure and $\mathrm{Hg}$ concentrations suggested in this study should help future interpretations of $\mathrm{Hg}$ concentrations in modern polar bears, which are also potentially affected by spatial variation in anthropogenic $\mathrm{Hg}$ deposition, and changes in the patterns of sea-ice cover and the associated impacts on local food-web structures.

\section{Acknowledgements}

We thank the National Museum of Natural History, the American Museum of Natural History and the Museum of Comparative Zoology, and their staff, for providing the 
requested polar bear hair specimens for analysis. This research was supported by a University of Puget Sound, University Enrichment Committee Faculty Research Grant (R04441) to TWH. We also thank three external referees for their thoughtful and detailed reviews of the initial manuscript.

\section{References}

Applequist H., Drabaek I. \& Asbirk S. 1985. Variation in mercury content of guillemot feathers over 150 years. Marine Pollution Bulletin 16, 244-248.

Ariya P.A., Dastoor A.P., Amyot M., Schroeder W.H., Barrie L., Anlauf K., Raofie F., Ryzhkov A., Davignon D., Lalonde J. \& Steffen A. 2004. The Arctic: a sink for mercury. Tellus, Series B: Chemical and Physical Meteorology 56, 397-403.

Arrigo K.R., Robinson D.H., Dunbar R.B., Leventer A.R. \& Lizotte M.P. 2003. Physical control of chlorophyll a, POC, and TPN distributions in the pack ice of the Ross Sea, Antarctica. Journal of Geophysical Research-Oceans 108, article no. 3316, doi: 10.1029/2001JC001138.

Atkinson A. 1998. Life cycle strategies of epipelagic copepods in the Southern Ocean. Journal of Marine Systems 15, 289-311.

Atwell L., Hobson K.A. \& Welch H.E. 1998. Biomagnification and bioaccumulation of mercury in an Arctic marine food web: Insights from stable nitrogen isotope analysis. Canadian Journal of Fisheries and Aquatic Sciences 55, 1114-1121.

Bentzen T.W., Follmann E.H., Amstrup S.C., York G.S., Wooler M.L. \& O'Hara T.M. 2007. Variation in winter diet of southern Beaufort Sea polar bears inferred from stable isotope analysis. Canadian Journal of Zoology 85, 596-608.

Bradstreet S.W. \& Cross W.E. 1982. Trophic relationships at high ice edges. Arctic 35, 1-12.

Braune B.M., Outridge P.M., Fisk A.T., Muir D.C.G., Helm P.A., Hobbs K., Hoekstra P.F., Kuzyk Z.A., Kwan M., Letcher R.J., Lockhart W.L., Norstrom R.J., Stern G.A. \& Stirling I. 2005. Persistent organic pollutants and mercury in marine biota of the Canadian Arctic: an overview of spatial and temporal trends. Science of the Total Environment 351-352, 4-56.

Budge S.M., Wooller M.J., Springer A.M., Iverson S.J., McRoy C.P. \& Divoky G.J. 2008. Tracing carbon flow in an Arctic marine food web using fatty acid-stable isotope analysis. Oecologia 157, 117-129.

Campbell L.M., Norstrom R.J., Hobson K.A., Muir D.C.G., Backus S. \& Fisk A.T. 2005. Mercury and other trace elements in a pelagic Arctic marine food web (Northwater Polynya, Baffin Bay). Science of the Total Environment 351-352, 247-263.

Dehn L., Follmann E.H., Thomas D.L., Sheffield G.G., Rosa C., Duffy L.K. \& O'Hara T.M. 2006. Trophic relationships in an Arctic food web and implications for trace metal transfer. Science of the Total Environment 362, 103-123.

Dehn L., Sheffield G.G., Follmann E.H., Duffy L.K., Thomas D.L., Bratton G.R., Taylor R.J. \& O'Hara T.M. 2005. Trace elements in tissues of phocid seals harvested in the Alaskan and Canadian Arctic: influence of age on feeding ecology. Canadian Journal of Zoology 83, 726-746.

Dietz R., Riget F., Boertmann D., Sonne C., Olsen M.T., Fjeldsa J., Falk K., Kirkegaard M., Egevang C., Asmucd G., Wille F. \& Moller S. 2006. Time trends of mercury in feathers of west Greenland birds of prey during 1851-2003. Environmental Science and Technology 40, 5911-5916.

Dietz R., Riget F., Born E.W., Sonne C., Grandjean P. Kirkegaard M., Olsen M.T., Asmund G., Renzoni A., Baagøe H. \& Andreasen C. 2006. Trends in mercury in hair of Greenlandic polar bears (Ursus maritimus) during 1892-2001. Environmental Science and Technology 40, 1120-1125.

Dietz R., Riget F. \& Johansen P. 1996. Lead, cadmium, mercury, and selenium in Greenland marine animals. Science of the Total Environment 186, 67-93.

Douglas T.A., Sturm M., Simpson W.R., Blum J.D., Alvarez-Aviles L., Keeler G.J., Perovich D.K., Biswas A. \& Johnson K. 2008. Influence of snow and ice crystal formation and accumulation on mercury deposition to the Arctic. Environmental Science and Technology 42, 1542-1551.

Eaton R.D.P. \& Farant J.P. 1982. The polar bear as a biological indicator of the environmental mercury burden. Arctic 35, 422-425.

Fitzgerald W.F., Engstrom D.R., Lamborg C.H., Tseng C.M., Balcom P.H. \& Hammerschmidt C.R. 2005. Modern and historic atmospheric mercury fluxes in northern Alaska: global sources and Arctic depletion. Environmental Science and Technology 39, 557-568.

Gosselin M., LeVasseur M., Wheeler P.A., Horner R.A. \& Booth B.C. 1997. New measurements of phytoplankton and ice algal production in the Arctic Ocean. Deep Sea Research Part I 44, 1623-1644.

Hassol S.J. 2004. Impacts of a warming Arctic. Cambridge, UK: Cambridge University Press.

Hilderbrand G.V., Farley S.D., Robbins C.T., Hanley T.A., Titus K. \& Servheen C. 1996. Use of stable isotopes to determine diets of living and extinct bears. Canadian Journal of Zoology 74, 2080-2088.

Hobson K.A., Fisk A., Karnovsky N., Holst M., Gagnon J.M. \& Fortier M. 2002. A stable isotope $\left(\delta^{13} \mathrm{C}, \delta^{15} \mathrm{~N}\right)$ model for the North Water food web: implications for evaluating trophodynamics and the flow of energy and contaminants. Deep Sea Research Part II 49, 5131-5150.

Hobson K.A., Sease J.L., Merrick R.L. \& Piatt J.F. 1997. Investigating trophic relationships of pinnipeds in Alaska and Washington using stable isotope ratios of nitrogen and carbon. Marine Mammal Science 13, 114-132.

Hobson K.A. \& Welch H.E. 1992. Determination of trophic relationships within a High Arctic marine food web using $\delta^{13} \mathrm{C}$ and $\delta^{15} \mathrm{~N}$ analysis. Marine Ecology Progress Series 84 , $9-18$.

Kelly J.F. 2000. Stable isotopes of carbon and in the study of avian and mammalian trophic ecology. Canadian Journal of Zoology 78, 1-27. 
Kurle C.M. 2002. Stable-isotope ratios of blood components from captive northern fur seals (Callorhinus ursinus) and their diet: applications for studying the foraging ecology of wild otariids. Canadian Journal of Zoology 80, 902-909.

Lu J.Y., Schroeder W.H., Barrie L.A., Steften A., Welch H.E., Martin K., Lockhart L., Hunt R.V., Boila G. \& Richter A. 2001. Magnification of atmospheric mercury deposition to polar regions in springtime: the link to tropospheric ozone depletion chemistry. Geophysical Research Letters 28, 3219-3222.

McMahon K.W., Ambrose W.G. Jr., Johnson B.J., Sun M.Y., Lopez G.R., Clough L.M. \& Carroll M.L. 2006. Benthic community response to ice algae and phytoplankton in $\mathrm{Ny}$ Ålesund, Svalbard. Marine Ecology Progress Series 310, 1-14.

Muir D.C.G., Segstro M.D., Hobson K.A., Ford C.A., Stewart R.E.A. \& Olpinski S. 1995. Can seal eating explain elevated levels of PCBs and organochlorine pesticides in walrus blubber from Eastern Hudson Bay (Canada)? Environmental Pollution 90, 335-348.

Norstrom R.J., Schweinsberg R.E. \& Collins B.T. 1986. Heavy metals and essential elements in livers of the polar bear (Ursus maritimus) in the Canadian Arctic. Science of the Total Environment 48, 195-212.

Outridge P.M., Hobson K.A. \& Savelle J.M. 2005. Changes in mercury and cadmium concentrations and the feeding behaviour of beluga (Delphinapterus leucas) near Somerset Island, Canada, during the 20th century. Science of the Total Environment 350, 106-118.

Outridge P.M., Stern G.A., Hamilton P.B., Percival J.B., McNeely R. \& Lockhart W.L. 2005. Trace metal profiles in the varved sediment of an Arctic lake. Geochimica et Cosmochimica Acta 69, 4881-4894.

Overpeck J.T., Sturm M., Francis J.A., Perovich D.K., Serreze M.C., Benner R., Carmack E.C., Chapin Iii F.S., Gerlach S.C., Hamilton L.C., Hinzman L.D., Holland M., Huntington H.P., Key J.R., Lloyd A.H., MacDonald G.M., McFadden J., Noone D., Prowse T.D., Schlosser P. \& Vörösmarty C. 2005. Arctic system on trajectory to new, seasonally ice-free state. EOS, Transactions of the American Geophysical Union 86, 312-313.

Poulain A.J., Garcia E., Amyot M., Campbell P.G.C., Raofie F. \& Ariya P.A. 2007. Biological and chemical redox transformations of mercury in fresh and salt waters of the High Arctic during spring and summer. Environmental Science and Technology 41, 1883-1888.

Quevauviller P., Maier E.A., Vercoutere K., Muntau H. \& Griepink B. 1992. Certified reference material (CRM 397) for the quality control of trace element analysis of human hair. Fresenius' Journal of Analytical Chemistry 343, 335-338.

Ramsay M.A. \& Hobson K.A. 1991. Polar bears make little use of terrestrial food webs: evidence from stable-carbon isotope analysis. Oecologia 86, 598-600.

Schell D.M., Barnett B.A. \& Vinette K.A. 1998. Carbon and nitrogen isotope ratios in zooplankton of the Bering, Chukchi and Beaufort seas. Marine Ecology Progress Series $162,11-23$.

Schuster P.F., Krabbenhoft D.P., Naftz D.L., Cecil L.D., Olson M.L., Dewild J.F., Susong D.D., Green J.R. \& Abbott M.L. 2002. Atmospheric mercury deposition during the last 270 years: a glacial ice core record of natural and anthropogenic sources. Environmental Science and Technology 36, 2303-2310.

Smetacek V. \& Nicol S. 2005. Polar ocean ecosystems in a changing world. Nature 437, 362-368.

Smith T.G. \& Armstrong F.A.J. 1975. Mercury in seals, terrestrial carnivores, and principal food items of the Inuit, from Holman, N.W.T. Journal of the Fisheries Research Board of Canada 32, 795-801.

Tamelander T., Renaud P.E., Hop H., Carroll M.L., Ambrose W.G. Jr. \& Hobson K.A. 2006. Trophic relationships and pelagic-benthic coupling during summer in the Barents Sea Marginal Ice Zone, revealed by stable carbon and nitrogen isotope measurements. Marine Ecology Progress Series 310, 33-46.

Tremblay J.E., Michel C., Hobson K.A., Gosselin M. \& Price N.M. 2006. Bloom dynamics in early opening waters of the Arctic Ocean. Limnology and Oceanography 51, 900-912.

Wagemann R., Innes S. \& Richard P.R. 1996. Overview and regional and temporal differences of heavy metals in Arctic whales and ringed seals in the Canadian Arctic. Science of the Total Environment 186, 41-66.

Wagemann R., Trebacz E., Boila G. \& Lockhart W.L. 1998. Methylmercury and total mercury in tissue of Arctic marine mammals. Science of the Total Environment 218, 19-31.

Welch H.E. 1992. Energy flow through the marine ecosystem of the Lancaster Sound region, Arctic Canada. Arctic 45, 343-357.

Woshner V.M., O'Hara T.M., Bratton G.R. \& Beasley V.R. 2001. Concentrations and interactions of selected essential and non-essential elements in ringed seals and polar bears of Arctic Alaska. Journal of Wildlife Diseases 37, 711-721. 